Gazi University
Journal of Science
PART A: ENGINEERING AND INNOVATION
http://dergipark.org.tr/gujsa

\title{
Artificial neural network predictive modelling of luffa cylindrica seed oil antioxidant yield
}

\author{
Kenechi NWOSU-OBİEOGU1*iD \\ ${ }^{1}$ Chemical Engineering Department, College of Engineering and Engineering Technology, Michael Okpara University, Umudike, Nigeria
}

\begin{tabular}{ll}
\hline Keywords & Abstract \\
\hline ANN & This study applied artificial neural network (ANN) in evaluating the models for terpineol and polyphenol \\
& yield from luffa cylindrica seed oil. The experiment was carried out at a temperature $\left(60-80^{\circ} \mathrm{C}\right)$, time $(4-$ \\
Terpineol & 6 hours), and solvent/seed ratio $(8-12 \mathrm{ml} / \mathrm{g})$ with response as antioxidant yield. FTIR $($ Fourier Transform \\
Polyphenol & Infra-red Spectroscopy) revealed the presence of terpineol and polyphenol at peaks of $1461.1 \mathrm{~cm}^{-1}$ and \\
Antioxidant & $3008.0 \mathrm{~cm}^{-1}$ respectively. The ANN prediction indices are thus; terpineol $\left(\mathrm{R}^{2}=9.9999 \mathrm{E}-1\right.$, \\
& $\mathrm{MSE}=2.25766 \mathrm{E}-9)$ and polyphenol $\left(\mathrm{R}^{2}=9.9999 \mathrm{E}-1, \mathrm{MSE}=4.42588 \mathrm{E}-10\right)$. This study reveals that the \\
& ANN technique can successfully predict antioxidants from luffa cylindrica seed oil. \\
\hline
\end{tabular}

\begin{tabular}{lcc}
\hline Cite & \\
\hline Nwosu-Obieogu, K. (2021). Artificial neural network predictive modelling of luffa cylindrica seed oil antioxidant yield. $G U J$ Sci, \\
$8(4), 494-504$. & Article Process \\
\hline Author ID (ORCID Number) & Submission Date & 15.07 .2021 \\
\hline K. Nwosu-Obieogu, 0000-0002-4920-8676 & Revision Date & 08.12 .2021 \\
& Accepted Date & 28.12 .2021 \\
& Published Date & 30.12 .2021
\end{tabular}

\section{INTRODUCTION}

Antioxidants occur naturally in vegetables and fruits, prevents free radical attack and reduce carcinogenic disease risk (Karadžić Banjac et al., 2018). In addition, studies have revealed that food rich in antioxidants (flavonoids, polyphenols, vitamins and minerals) has positive health impacts. Hence, their regular consumption reduces cardiovascular diseases, vision problems, high blood cholesterol and cancer. (Ohlsson \& Bengtsson, 2002; Liyana-Pathirana et al., 2006; Gonçalves et al., 2012).

Luffa cylindrica is a non-edible fibrous vegetable with fruits containing black seeds found in the tropics, a Cucurbitaceae, intensifying considerable attention from researchers to harness its potentials (Oboh \&Aluyor, 2009). However, antioxidants in leaves and fruits of luffa cylindrica have been revealed to offer interesting economic values. (Oyetayo \& Ojo, 2012).

Reports have shown that luffa-based derivatives constitute antioxidants such as terpineol, polyphenol present in our food, applied in the treatment of various ailments, and cosmetics production. (Vladimir-Knežević et al. 2011; Park et al., 2012; Zengin \& Baysal, 2014; Akinsanmi et al., 2015; Shendge \& Belemkar, 2018; Yu et al., 2018; Okla et al., 2019). (Vladimir-Knežević et al. (2011), Zengin \& Baysal (2014), and Campone et al. (2020) have researched extensively on terpineol and polyphenol extraction from plants. However, the relationship between factors that affect the extraction process and its response (polyphenol/terpineol yield)) is uncertain and complex from earlier reports (Khaleel et al., 2018; Molina et al., 2019; Sales et al., 2020).

ANN has shown its capability of controlling imprecise relationships among variables (Maosudi et al., 2018); ANN comprises mathematical models that apply biological neurons in solving intricate and uncertain processes, hence can be relied upon than linear and multivariate statistical procedures that have shown their 
inefficiency in handling nonlinear trends in data. (Almeida, 2002; Soto et al., 2019; Ojediran et al., 2020; Oke et al., 2020; 2021).

ANN modeling approach has been proven as a reliable technique in antioxidant yield estimation of plants, thus, the antioxidant properties of bananas (Guiné et al., 2015), beet-root (Kovacević et al., 2015), tea (Cimpoiu et al., 2011), polyphenols from green tea (Xi et al., 2013), essential oils (Cabrera \& Prieto, 2010), polyphenols from pine fallen foliage (Vats \& Negi, 2013), blueberries (Guiné et al., 2018) and lettuce (Karadžić Banjac et al., 2018) have been predicted successfully by ANN. However, there is sparse literature on antioxidant yield from vegetable seed oil. Thus, this study predicts polyphenol and terpineol yield from luffa cylindrica seed oil using the ANN model.

\section{MATERIAL AND METHOD}

\subsection{Sample Preparation}

Luffa cylindrica fruits were procured from nearby bushes at Amawom, Umuahia, Nigeria. The seed was winnowed, husks and dirt removed, after which it was sun-dried for easy removal of the shell and was also oven-dried at $60^{\circ} \mathrm{C}$ to constant weight before grinding to increase the surface area for oil extraction.

The experimental matrix was designed using Design-Expert version 10, where Box-Behnken implementing response surface methodology on a three factors and three-level basis was employed to generate seventeen runs. The factors include time, temperature, and seed/solvent ratio, and the response is polyphenol/terpineol yield. The summary is shown in Table 1.

Table 1. Design of Experiment

\begin{tabular}{|l|l|c|c|c|}
\hline \multirow{2}{*}{ Factors } & \multirow{2}{*}{ Units } & \multicolumn{3}{|c|}{ Level } \\
\cline { 3 - 5 } & & $\mathbf{- 1}$ & $\mathbf{0}$ & $\mathbf{1}$ \\
\hline Temperature & ${ }^{\circ} \mathrm{C}$ & 60 & 70 & 80 \\
\hline Time & Hour & 4 & 5 & 6 \\
\hline Solvent/seed & $\mathrm{ml} / \mathrm{g}$ & 8 & 10 & 12 \\
\hline
\end{tabular}

\subsection{Experimental Procedure}

Luffa oil extraction process was carried out at Chemical Engineering Department laboratory, Michael Okpara University of Agriculture Umudike, Abia State, Nigeria, using the method described by (Afolabi et al., 2014). $40 \mathrm{~g}$ of grounded luffa seed was utilized for each experimental run. $250 \mathrm{~cm}^{3}$ capacity Soxhlet apparatus and $n$ hexane of analytical grade was employed for the process. The solvent was recovered at every interval and the obtained oil was weighed, the oil yield was calculated using the equation below.

$$
Y=\frac{M_{\mathrm{o}}}{M_{\mathrm{s}}} \times 100
$$

$$
\begin{aligned}
& \text { Where: } \quad Y \quad \text { : oil yield (\%) } \\
& M_{\mathrm{o}} \quad: \text { mass of oil extracted }(\mathrm{g}) \\
& M_{\mathrm{s}} \quad \text { : mass of luffa seed (g) }
\end{aligned}
$$

\subsubsection{Terpineol Concentration Determination}

The terpineol concentration was determined using a method modified by Ghorai et al. (2017). $0.1 \mathrm{~g}$ of the luffa oil was introduced into a test tube, $1 \mathrm{ml}$ methanol was added, placed in a water bath, it was stirred for 30minutes at a temperature of $100^{\circ} \mathrm{C}, 1 \mathrm{ml}$ sulphuric acid was introduced, the colour turned to reddish-brown, it was allowed to stand for 30minutes then the absorbance was taken in a UV spectrophotometer, the standard curve was generated by treating the linalool as the sample with serial dilution. 


\subsubsection{Polyphenol Yield Determination}

The total polyphenol content was determined using the Folin Ciocalteu method by Singleton \& Rossi (1965). About $0.1 \mathrm{~g}$ of the oil extract was weighed in a test tube, $1 \mathrm{ml}$ of methanol was introduced into a water bath and shaker, where it was allowed to shake for 30 minutes at $40^{\circ} \mathrm{C}$. Next, the sample was removed, and $1 \mathrm{ml}$ of FolinCiocalteu and $2 \mathrm{ml}$ of $20 \% \mathrm{Na}_{2} \mathrm{CO}_{3}$ were introduced; the mixture was allowed to stand for 10 minutes before it was stirred in a centrifuge for 20minutes at 400rpm; the absorbance was taken using a UV spectrophotometer at $625 \mathrm{~nm}$. The standard curve was generated by preparing different concentrations ranging from $10 \mathrm{mg} / 1$ of Gallic acid.

\subsubsection{FT-IR Analysis}

Fourier transform infrared (FTIR) analysis was carried out to determine the functional groups present on luffa oil using the FTIR spectroscope (PerkinElmer Spectrum one v3.02 Spectrometer, India).

\subsection{ANN Model Development}

ANN modeling of the extraction process was developed using the neural fitting toolbox of MATLAB R2014b. The architecture consists of 3 input layers (temperature, time and solute/solvent ratio), two output layers (polyphenol and terpineol yield) and a hidden layer. The dataset obtained from the extraction process was split into (training, validation and testing) with $70 \%, 15 \%$, and $15 \%$. The ANN structure is presented in Figure 1. To determine the best algorithm for the prediction, MSE and $\mathrm{R}^{2}$ were used as the statistical criteria to assess the algorithm's performance. (Uzuner \& Cekmecelioglu, 2016; Masoudi et al., 2018; Nwosu-Obieogu et al., 2020).

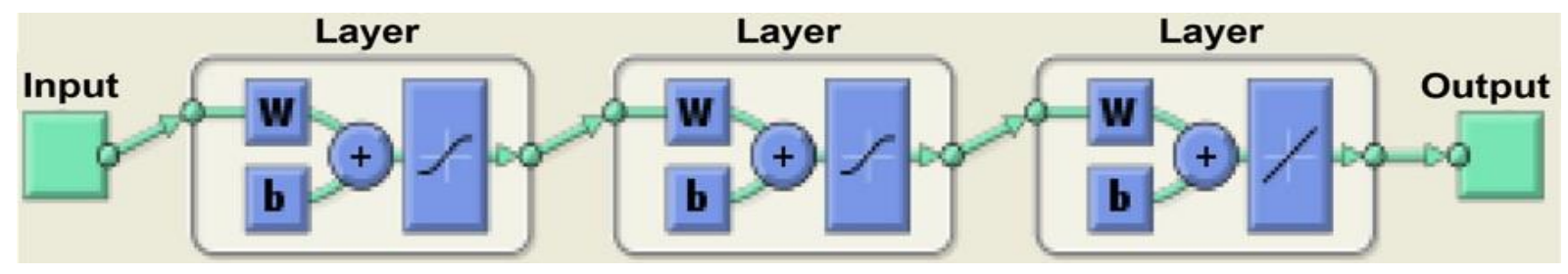

Figure. 1. ANN Structure

\section{RESULTS AND DISCUSSION}

\subsection{Antioxidant Yields from luffa oil}

The maximum terpineol yield of $2657 \mathrm{ml} / \mathrm{g}$ was obtained at a solvent/ solute concentration of $12 \mathrm{~mol} / \mathrm{g}$, temperature of $80^{\circ} \mathrm{C}$, and a time of 5hours, while polyphenol yield of $609.37 \mathrm{ml} / \mathrm{g}$ was obtained at a solvent/solute ratio concentration of $10 \mathrm{~mol} / \mathrm{g}$, the temperature of $80^{\circ} \mathrm{C}$ and time of 6 hours as shown in Table 2 , increase in process parameters led to an increase in terpineol and polyphenol yield, indicating that the factors had a significant effect on the antioxidant product (Afolabi et al.,2014; Oniya et al., 2017; Yu et al., 2018). The data were utilised in ANN prediction of terpineol and polyphenol yield (Nwosu-Obieogu et al., 2020).

The ANN-based model was developed based on the feed-forward, backpropagation (BP) algorithms. The hidden layer comprises ten neurons; the coefficient of determination $\left(\mathrm{R}^{2}\right)$ value at training, validation and testing is 1 for terpineol yield, while the polyphenol yield prediction gave 1 for training and testing, and 0.99996 for confirmation, as shown in Figure 2 and 3; these indicate the level of variability of the experimental results captured by the predicted. As shown in Table 3 and 4, the Bayesian regularization was the best of the algorithms for terpineol and polyphenol yield, having the smallest MSE of 2.25766E-9 and 4.42588E-10, respectively; the optimal results were obtained at epoch 901 and 701 for terpineol and polyphenol yield as shown in Figure 4 and 5, these comparisons indicate that the model predicted antioxidants yield from luffa oil appropriately; The effectiveness of the expected ANN model results is in agreement with reports from (Uzuner \& Cekmecelioglu, 2016; Karadžić Banjac et al., 2018; Oke et al., 2020; Adeniyi et al., 2021). 
Table 2. Experimental Values for the Total Terpineol/Polyphenol Yield

\begin{tabular}{|c|c|c|c|c|c|}
\hline Runs & $\begin{array}{c}\text { Time } \\
(\text { hours })\end{array}$ & $\begin{array}{c}\text { Temperature } \\
\left({ }^{\mathbf{C}} \mathbf{C}\right)\end{array}$ & $\begin{array}{c}\text { Solvent/seed ratio } \\
(\mathbf{m l} / \mathbf{g})\end{array}$ & $\begin{array}{c}\text { Terpineol yield } \\
(\mathbf{g} / \mathbf{m l})\end{array}$ & $\begin{array}{c}\text { Polyphenol yield } \\
(\mathbf{g} / \mathbf{m l})\end{array}$ \\
\hline $\mathbf{1}$ & 5 & 70 & 10 & 1613 & 258.43 \\
\hline $\mathbf{2}$ & 5 & 70 & 10 & 1613 & 258.43 \\
\hline $\mathbf{3}$ & 4 & 80 & 10 & 1091 & 266.67 \\
\hline $\mathbf{4}$ & 4 & 70 & 12 & 1109 & 183.82 \\
\hline $\mathbf{5}$ & 4 & 60 & 10 & 713 & 107.43 \\
\hline $\mathbf{6}$ & 5 & 70 & 10 & 1613 & 258.43 \\
\hline $\mathbf{7}$ & 6 & 80 & 10 & 1724 & 609.37 \\
\hline $\mathbf{8}$ & 5 & 60 & 8 & 978 & 340.1 \\
\hline $\mathbf{9}$ & 6 & 60 & 10 & 1858 & 228.35 \\
\hline $\mathbf{1 0}$ & 5 & 80 & 8 & 1639 & 128.57 \\
\hline $\mathbf{1 1}$ & 5 & 80 & 12 & 2657 & 393.16 \\
\hline $\mathbf{1 2}$ & 5 & 70 & 10 & 1613 & 258.43 \\
\hline $\mathbf{1 3}$ & 5 & 60 & 12 & 1700 & 156.86 \\
\hline $\mathbf{1 4}$ & 5 & 70 & 10 & 1613 & 258.43 \\
\hline $\mathbf{1 5}$ & 4 & 70 & 8 & 668 & 151.72 \\
\hline $\mathbf{1 6}$ & 6 & 70 & 8 & 1534 & 145.35 \\
\hline $\mathbf{1 7}$ & 6 & 70 & 12 & 2172 & 126.92 \\
\hline
\end{tabular}
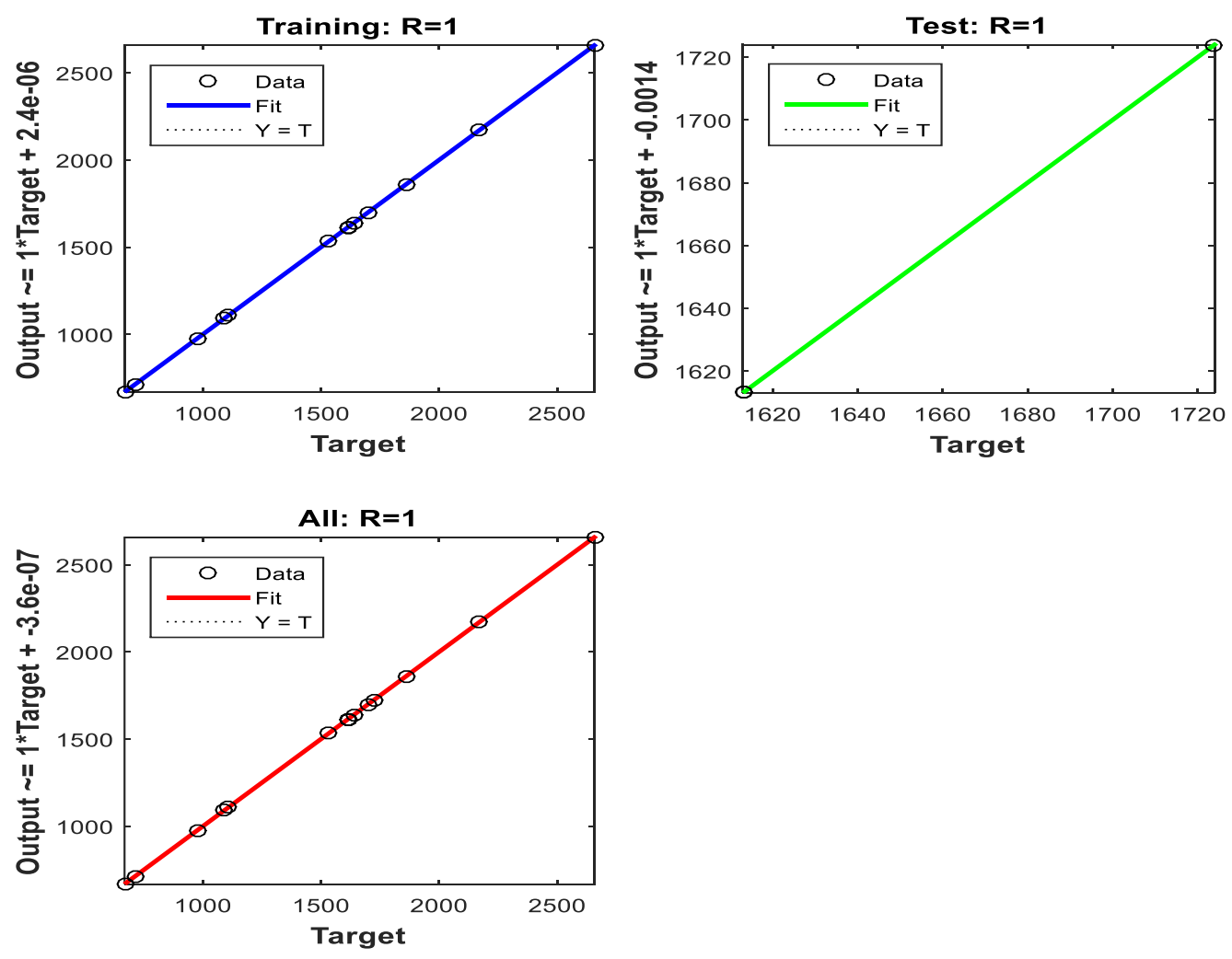

Figure 2. ANN Regression Graph for Terpineol Yield Prediction 

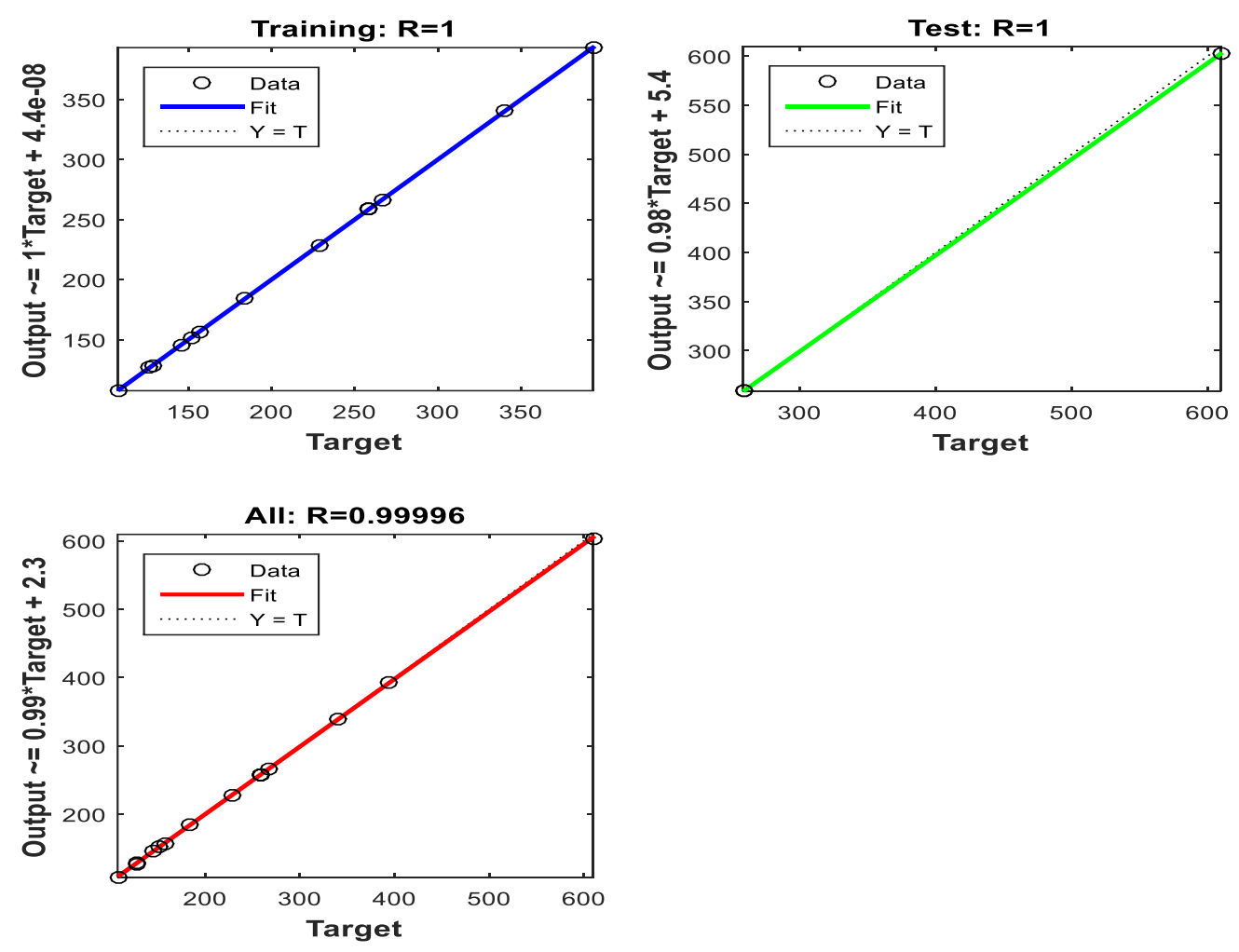

Figure 3. ANN Regression Graph for Polyphenol Yield Prediction

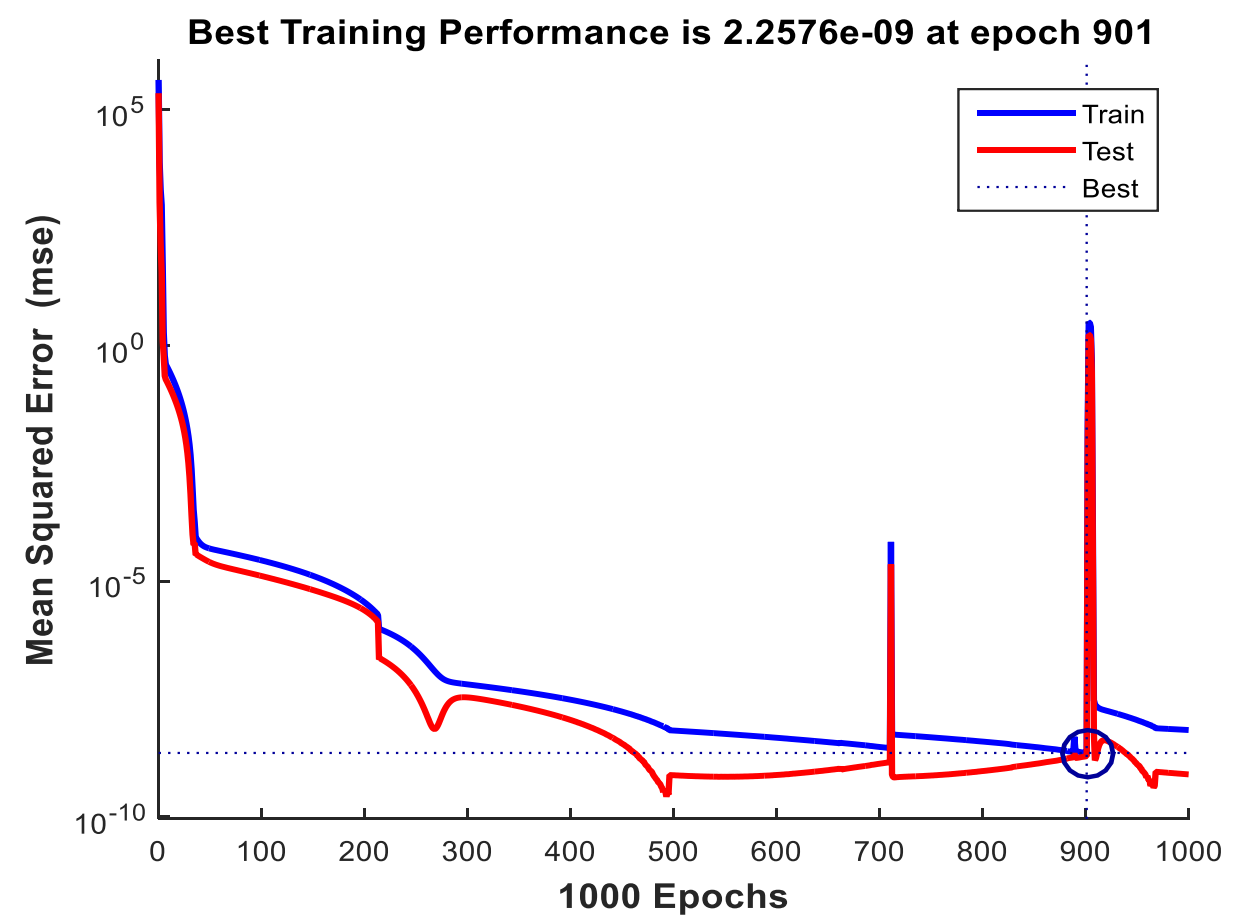

Figure 4. Training Error (mean squared error, MSE) Curve for Terpineol Yield Prediction 


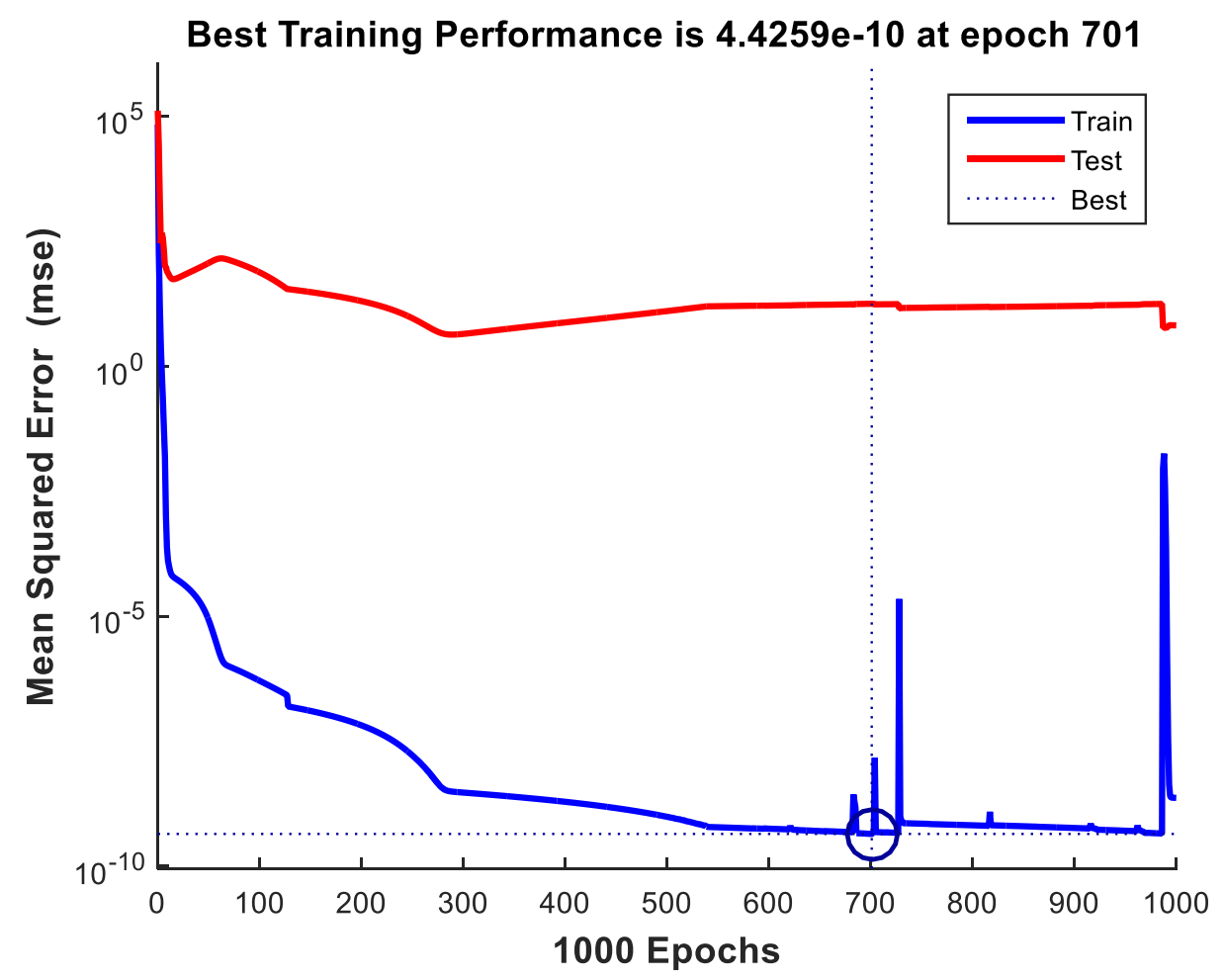

Figure 5. Training Error (mean squared error, MSE) Curve for Polyphenol Yield Prediction

Table 3. Comparison of the ANN Algorithm for Terpineol Yield

\begin{tabular}{|c|l|c|c|}
\hline $\mathbf{S} / \mathbf{N}$ & Algorithm & MSE & $\mathbf{R}^{2}$ \\
\hline 1 & Levenberg-Marquardt & $4523.36933 \mathrm{E}-0$ & 0.9935 \\
\hline 2 & Bayesian Regularization & $\mathbf{2 . 2 5 7 6 6 E - 9}$ & $\mathbf{0 . 9 9 9 9}$ \\
\hline 3 & Scaled Conjugate Gradient & $401381.42860 \mathrm{E}-0$ & 0.0011 \\
\hline 4 & trainrp & $5.0602 \mathrm{E} 4$ & 0.9436 \\
\hline 5 & traincgf & $1.1738 \mathrm{E} 05$ & 0.9998 \\
\hline 6 & traincgp & $1.4700 \mathrm{E} 05$ & 0.9732 \\
\hline 7 & traincgb & $1.2690 \mathrm{E} 04$ & 0.9889 \\
\hline 8 & trainbfg & $1.3758 \mathrm{E} 05$ & 0.9829 \\
\hline 9 & trainoss & $1.5833 \mathrm{E} 04$ & 0.9971 \\
\hline 10 & traingd & $1.5693 \mathrm{E} 06$ & 0.3644 \\
\hline 11 & traingdx & $2.0683 \mathrm{E} 05$ & 0.9433 \\
\hline 12 & traingdm & $2.6889 \mathrm{E} 06$ & 0.8609 \\
\hline
\end{tabular}


Table 5 shows the antioxidant yield of luffa oil compared to guava plant, lemon plant, Sorghum Moench and apple pomace; the yield of $2657 \mathrm{mg} / \mathrm{l}$ for terpineol compared to the result of $348 \mathrm{ml} / \mathrm{g}$ and $97 \mathrm{ml} / \mathrm{g}$ for guava and lemon plant respectively and, $609.37 \mathrm{ml} / \mathrm{g}$ of polyphenol compared to $313 \mathrm{ml} / \mathrm{g}$ and $775 \mathrm{ml} / \mathrm{g}$ for sorghum Moench and apple pomace, respectively, indicates that luffa oil contains plenty of antioxidants that can be harnessed to proper use.

Table 4. Comparison of the ANN Algorithm for Polyphenol Yield

\begin{tabular}{|c|l|c|c|}
\hline S/N & Algorithm & MSE & $\mathbf{R}^{\mathbf{2}}$ \\
\hline 1 & Levenberg-Marquardt & $4.75287 \mathrm{E}-1$ & 0.9998 \\
\hline 2 & Bayesian Regularization & $\mathbf{4 . 4 2 5 8 8 E - 1 0}$ & $\mathbf{0 . 9 9 9 9}$ \\
\hline 2 & Scaled Conjugate Gradient & $4220.33975 \mathrm{E}-0$ & 0.8912 \\
\hline 3 & trainrp & $1.2821 \mathrm{E} 04$ & 0.9315 \\
\hline 4 & traincgf & 400.1718 & 0.9980 \\
\hline 5 & traincgp & $3.2516 \mathrm{E} 03$ & 0.9998 \\
\hline 6 & traincgb & $9.4288 \mathrm{E} 03$ & 0.9921 \\
\hline 7 & trainbfg & $1.7404 \mathrm{E} 04$ & 0.5519 \\
\hline 8 & trainoss & 648.1305 & 0.9924 \\
\hline 9 & traingd & $2.7824 \mathrm{E} 05$ & 0.8954 \\
\hline 10 & traingdx & $2.4738 \mathrm{E} 03$ & 0.8351 \\
\hline 11 & traingdm & $1.4876 \mathrm{E} 05$ & 0.9994 \\
\hline
\end{tabular}

Table 5. Comparison of Terpineol and Polyphenol Present in Some Seed Oils with Luffa Seed Oil

\begin{tabular}{|c|c|c|}
\hline Oils & Terpineol yield (g/ml) & Polyphenol yield (g/ml) \\
\hline Luffa seed oil (present study) & & - \\
\hline Guava plant & 348 (de Lima et al., 2010) & \\
\hline Lemon plant & 97 (Ferhat et al., 2007) & 313 (Liu et al., 2018) \\
\hline Sorghum Moench & - & 775 (Skrypnik \&Novikova, 2020) \\
\hline Apple pomace & & \\
\hline
\end{tabular}

\subsection{FTIR Result}

The FT-IR results of the oil yield from luffa cylindrica is shown in Figure 6, the peak at $3008.0 \mathrm{~cm}^{-1}$ can be ascribed to $-\mathrm{OH}$ stretching, which indicates the presence of polyphenol, two sharp-pointed peaks at 2922.2 $\mathrm{cm}^{-1}$ and $2855.1 \mathrm{~cm}^{-1}$ indicated alkane group, another sharply pointed peak with value $1744 \mathrm{~cm}^{-1}$ indicates the presence of esters (6-membered lactone) with the structure $\mathrm{C}=\mathrm{O}$, hence the oil has high saponification value 
and could be recommended for soap production. The shorter, smaller pointed peak with a vibrational mode at $1461.1 \mathrm{~cm}^{-1}$ indicates the presence of terpineol (Agatonovic-Kustrin et al., 2020), while a medium sharp peak was observed with a value of $1379 \mathrm{~cm}^{-1}$, indicating an alkane of gem dimethyl group. The peak at $1237.5 \mathrm{~cm}^{-1}$ indicates an alkyl aryl ether with structure $\mathrm{C}-\mathrm{O}-\mathrm{C}$, while $987.7 \mathrm{~cm}^{-1}$ and $723.1 \mathrm{~cm}^{-1}$ peaks indicated alkene compounds. The presence of unsaturated hydrocarbons makes oil suitable for plastic and paint industries, as a drying agent in the production of cosmetics, and may be edible for animal feed (Oli et al., 2014).

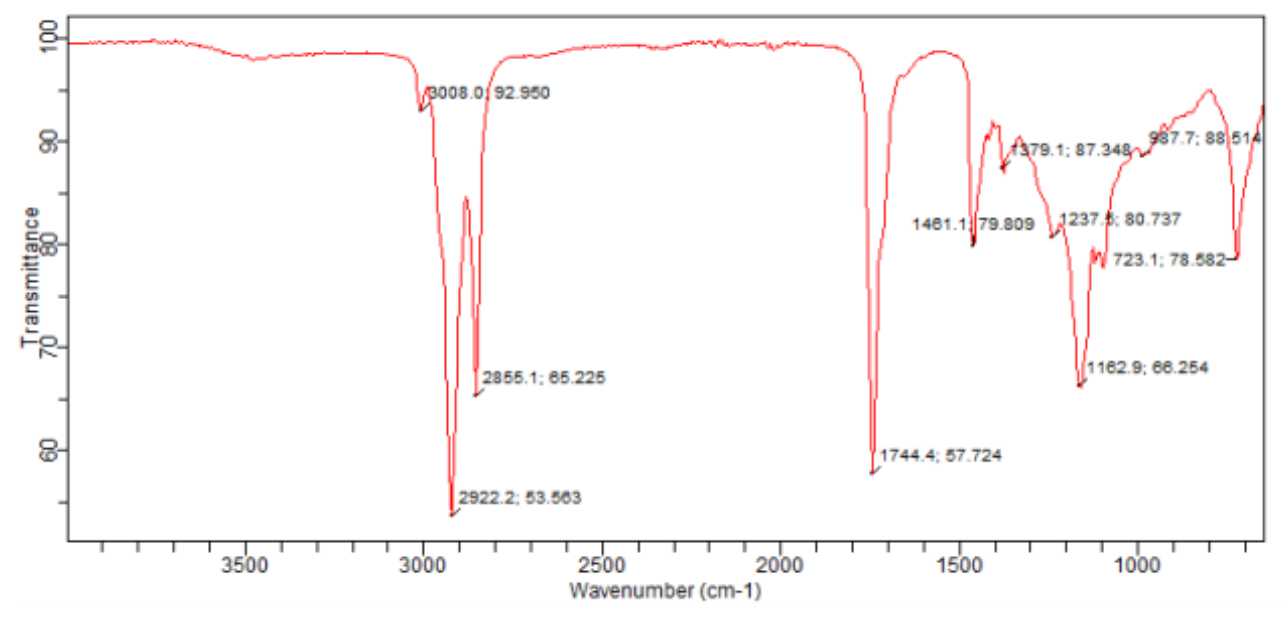

Figure 6 FT-IR Result of the Oil Yield

\section{CONCLUSION}

In this study, ANN has been applied to model antioxidant yields from luffa oil. Various conclusions were drawn from the findings. The coefficient of determination $\left(\mathrm{R}^{2}\right)$ value at validation was 1 for terpineol yield with optimal results obtained at epoch 901 and 0.99996 for polyphenol yield with optimal results obtained at epoch 701, the accuracy of the model was validated with experimental results. The study's findings are relevant in designing and developing a dynamic neural network controller for antioxidant production from vegetable seed oils.

\section{ACKNOWLEDGEMENT}

The author acknowledges the staff working in the unit operation laboratory, chemical engineering department, Michael Okpara University of Agriculture, Umudike, that assisted us with the necessary apparatus and reagents needed for the extraction process.

\section{CONFLICT OF INTEREST}

The author declares no conflict of interest.

\section{REFERENCES}

Adeniyi, A. G., Igwegbe, C. A. \& Ighalo, J. O. (2021) ANN modelling of the adsorption of herbicides and pesticides based on sorbate-sorbent interphase. Chemistry Africa, 4, 443-449. doi:10.1007/s42250-020-00220$\underline{\mathrm{w}}$

Afolabi, T. J., Onifade, K. R., Akindipe, V. O. \& Odetoye, T. E. (2014). Optimization of Solvent Extraction of Parinari polyandra Benth Seed Oil Using Response Surface Methodology. British Journal of Applied Science \& Technology, 5(5), 436-446.

Agatonovic-Kustrin, S., Ristivojevic, P., Gegechkori, V., Litvinova, T. M., Morton, D. W. (2020). Essential oil quality and purity evaluation via FT-IR spectroscopy and pattern recognition techniques. Applied sciences, 10(20), 1-12. doi:10.3390/app10207294 
Akinsanmi, A. O., Oboh, G., Akinyemi, J. A., \& Adefagha, A. S. (2015). Assessment of the nutritional, antinutritional, and antioxidant capacity of unripe, ripe, and overripe plantain (Musa paradisiaca) peels. International Journal of Advanced Research, 3(2), 63-72.

Almeida, J. S. (2002) Predictive Non-linear Modelling of Complex Data by Artificial Neural Networks. Current Opinion in Biotechnology, 13(1), 72-76. doi:10.1016/s0958-1669(02)00288-4

Cabrera, A. C. \& Prieto, J. M. (2010) Application of artificial neural networks to the prediction of the antioxidant activity of essential oils in two experimental in vitro models. Food Chemistry, 118(1), 141-146. doi:10.1016/j.foodchem.2009.04.070

Campone, L., Celano, R., Rizzo, S., Piccinelli, A. L., Rastrelli, L., \& Russo, M. (2020). Development of an Enriched Polyphenol (Natural Antioxidant) Extracts from Orange Juice (Citrus sinensis) by Adsorption on Macroporous Resins. Journal of Food Quality, 1251957, 1-9. doi:10.1155/2020/1251957

Cimpoiu, C., Cristea, V-M., Hosu, A., Sandru, M., \& Seserman, L. (2011) Antioxidant activity prediction and classification of some teas using artificial neural networks. Food Chemistry, 127(3), 1323-1328. doi:10.1016/j.foodchem.2011.01.091

de Lima, R. K., Cardoso, M. das G., Andrade, M. A., Nascimento, E. A., de Morais, S. A. L., \& Nelson, D. L. (2010). Composition of the essential oil from the leaves of tree domestic varieties and one wild variety of the guava plant (Psidium guajava L., Myrtaceae). Revista Brasileira de Farmacognosia, 20(1), 41-44. doi:10.1590/S0102-695X2010000100009

Ferhat, M. A., Meklati, B. Y., \& Chemat, F. (2007). Comparison of different isolation methods of essential oil from Citrus fruits: cold pressing, hydrodistillation and microwave 'dry' distillation. Flavour and Fragrance Journal, 22(6), 494-504. https://doi.org/10.1002/ffj.1829

Ghorai, N., Chakraborty, S., Gucchait, S., Saha, S. K., \& Biswas, S. (2012). Estimation of total terpenoids concentration in plant tissues using a monoterpene, linalool as the standard reagent. Protocol Exchange. doi:10.1038/PROTEX.2012.055

Gonçalves, F. J., Rocha, S. M., \& Coimbra, M. A. (2012) Study of the retention capacity of anthocyanins by wine polymeric material. Food Chemistry, 134(2), 957-963. doi:10.1016/j.foodchem.2012.02.214

Guiné, R. P. F., Barroca, M. J., Gonçalves, F. J., Alves, M., Oliveira, S., \& Mendes, M. (2015) Artificial neural network modelling of the antioxidant activity and phenolic compounds of bananas submitted to drying treatments. Food Chemistry, 168, 454-459. doi:10.1016/j.foodchem.2014.07.094

Guiné, R. P. F, Matos, S., Goncalves, F. J., Costa, D. \& Mendes M. (2018) Evaluation of phenolic compounds and antioxidant activity of blueberries and modelization by artificial neural networks. International Journal of Fruit Science, 18(2), 199-214. doi:10.1080/15538362.2018.1425653

Karadžić Banjac, M. Ž., Kovačević, S. Z., Jevrić, L. R., Podunavac-Kuzmanović, S. O., Tepić Horecki, A. N., Vidović, S. S., Šumić, Z. M., Ilin, Ž. M., Adamović, B. D., \& Kuljanin, T. A. (2018). Artificial neural network modelling of the antioxidant activity of lettuce submitted to different postharvest conditions. Journal of Food Processing and Preservation, 43(3), e13878. doi:10.1111/jfpp.13878

Khaleel, C., Tabanca, N., \& Buchbauer, G., (2018). $\alpha$-Terpineol, a natural monoterpene: A review of its biological properties. Open Chemistry, 16(1), 349-361. doi:10.1515/chem-2018-0040

Kovacević, S. Z., Jevrić, L. R., Podunavac-Kuzmanović, S. O., Kalaidiziia, N. D., \& Loncar, E. S. (2015) Quantitative structure-retention relationship analysis of some xylofuranose derivatives by linear multivariate method. Acta Chimica Slovenica, 60(2), 420-428. doi:10.17344/acsi.2014.888

Liu, L., Chen, L., Abbasi, A. M., Wang, Z., Li, D., \& Shen, Y. (2018) Optimization of extraction of polyphenols from Sorghum Moench using response surface methodology, and determination of their antioxidant activities. Tropical Journal of Pharmaceutical Research, 17(4), 619-626. doi:10.4314/tjpr.v17i4.8

Liyana-Pathirana, C. M., Shahidi, F., \& Alasalvar, C. (2006). Antioxidant activity of cherry laurel fruit (Laurocerasus officinalis Roem.) and its concentrated juice. Food Chemistry, 99(1), 121-128. doi:10.1016/j.foodchem.2005.06.046 
Maosudi, S., Sima, M., \& Tolouei-Rad, M. (2018). Comparative study of ANN and ANFIS models for predicting temperature in machining. Journal of Engineering Science and Technology, 13(1), 211-225.

Molina, G., Pessôa, M. G., Bicas, J. L., Fontanille, P., Larroche, C., \& Pastore, G. M. (2019). Optimization of limonene biotransformation for the production of bulk amounts of $\alpha$-terpineol. Bioresource Technology, 294, 122180. doi:10.1016/j.biortech.2019.122180

Nwosu-Obieogu, K., Aguele, F. \& Chiemenem, L. I. (2020) Soft computing prediction of oil extraction from huracrepitan seeds. Kem. Ind., 69(12), 653-658. doi:10.15255/KUI.2020.006

Oboh, I. O. \& Aluyor, E. O. (2009). Luffa cylindrica-an emerging cash crop. African Journal of Agricultural Research, 4(8), 684-688. doi:10.5897/AJAR.9000476

Ohlsson, T. \& Bengtsson, N. (2002). Minimal processing technologies in the food industry. Woodhead Publishing.

Ojediran, J. O., Okonkwo, C. E., Adeyi, A. J., Adeyi, O., Olaniran, A. F., George, N. E., \& Olayanju, A. T. (2020) Drying characteristics of yam slices (Dioscorea rotundata) in a convective hot air dryer: application of ANFIS in the prediction of drying kinetics. Heliyon, 6(3), e03555. doi:10.1016/j.heliyon.2020.e03555

Oke, E. O., Nwosu-Obieogu, K., \& Ude, J. C. (2020) Experimental Study and Exergy Efficiency Prediction of Three-Leaved Yam (Dioscorea Dumetorum) Starch Drying. International Journal of Exergy, 33(4), 427-443. doi:10.1504/IJEX.2020.111690

Oke, E. O., Nwosu-Obieogu, K., Okolo, B., I., Adeyi, O., Omotoso, A. O., \& Ude, C. U. (2021) Hevea brasiliensis oil epoxidation: hybrid genetic algorithm-neural fuzzy-Box-Behnken (GA-ANFIS-BB) modelling with sensitivity and uncertainty analyses. Multiscale and Multidisciplinary Modelling, Experiments and Design, 4, 131-144. doi:10.1007/s41939-020-00086-y

Okla, M. K., Alamri, S. A., Salem, M. Z. M., Ali, H. M., Behiry, S. I., Nasser, R. A., Alaraidh, I. A., Al-Ghtani, S. M., \& Soufan, W. (2019). Yield, Phytochemical Constituents, and Antibacterial Activity of Essential Oils from the Leaves/Twigs, Branches, Branch Wood, and Branch Bark of Sour Orange (Citrus aurantium L.). Processes, 7(6), 363. doi:10.3390/pr7060363

Oli, C. C., Onuegbu, T. U., \& Ezeudu. E. C. (2014). Proximate composition, characterization, and spectroscopic analysis of luffa aegyptiaca seed. International Journal of Life Sciences Biotechnology and pharma Research, 3(4), 194-200.

Oniya, O. O., Oyelade, J. O., Ogunkunle, O., \& Idowu, D. O. (2017) Optimization of Solvent extraction of Oil from Sandbox Kernels (Hura crepitans L.) by a Response Surface Method. Energy and Policy Research, 4(1), 36-43. doi: $10.1080 / 23815639.2017 .1324332$

Oyetayo, F. L., \& Ojo, B. A., (2012). Food value and phytochemical composition of Luffa cylindrica seed flour. American Journal of Biochemistry, 2(6), 98-103. doi:10.5923/j.ajb.20120206.02

Park, S-N., Lim, Y. K., Friere, M. O., Cho, E., Jin, D., \& Kook, J-K. (2012). Antimicrobial effect of linalool and $\alpha$-terpineol against periodontopathic and cariogenic bacteria. Anaerobe, 18(3) 369-372. doi:10.1016/j.anaerobe.2012.04.001

Sales, A., Felipe, L. de O., \& Bicas, J. L. (2020). Production, Properties, and Applications of $\alpha$-Terpineol. Food and Bioprocess Technology, 13, 1261-1279. doi:10.1007/s11947-020-02461-6

Shendge, P. N., \& Belemkar, S., (2018). Therapeutic Potential of Luffa acutangula: A Review on Its Traditional Uses, Phytochemistry, Pharmacology and Toxicological Aspects. Frontiers in Pharmacology, 9. doi:10.3389/fphar.2018.01177

Singleton, V. L., \& Rossi, J. A., (1965). Colorimetry of total phenolics with phosphomolybdic-phosphotungstic acid reagents. Am J Enol Vitic, 16(3), 144-158.

Skrypnik, L., \& Novikova, A. (2020) Response Surface Modeling and Optimization of Polyphenols Extraction from Apple Pomace Based on Nonionic Emulsifiers. Agronomy, 10(1), 92. doi:10.3390/agronomy 10010092 
Soto, J., Castilo, O., Melin, P., \& Pedrycz, W. (2019) A new approach to multiple time series predictions using MIMO fuzzy aggregation models with modular neural networks. International Journal of Fuzzy Systems, 21, 1629-1648. doi:10.1007/s40815-019-00642-w

Uzuner, S., \& Cekmecelioglu, D. (2016). Comparison of Artificial neural networks (ANN) and Adaptive Neuro-fuzzy inference system (ANFIS) models in simulating polygalacturonase production. Bioresources, 11(4), 8676-8685. doi:10.15376/biores.11.4.8676-8685

Vats, S. \& Negi, S. (2013) Use of artificial neural network (ANN) for the development of bioprocess using Pinus roxburghii fallen foliages for the release of polyphenols and reducing sugars. Bioresource Technology, 140, 392-398. doi:10.1016/j.biortech.2013.04.106

Vladimir-Knežević, S., Blažeković, B., Štefan, M. B. \& Babac, M. (2011). Plant polyphenols as antioxidants influencing the human health. In: V. Rao (Eds.), Phytochemicals as Nutraceuticals - Global Approaches to Their Role in Nutrition and Health (pp. 155-180), IntechOpen. doi:10.5772/27843

Xi, J., Xue, Y., Xu, Y. \& Shen, Y. (2013) Artificial neural network modelling and optimization of ultrahighpressure extraction of green tea polyphenols. Food Chemistry, 141(1), 320-326. doi:10.1016/j.foodchem.2013.02.084

Yu, L., Jin, W., Li, X., \& Zhang, Y. (2018). Optimization of bioactive ingredient extraction from Chinese herbal medicine Glycyrrhiza glabra: a comparative study of three optimization models. Evidence-Based Complementary and Alternative Medicine, 6391414. doi:10.1155/2018/6391414

Zengin, H., \& Baysal, A. H. (2014). Antibacterial and antioxidant activity of essential oil terpenes against pathogenic and spoilage-forming bacteria and cell structure-activity relationships evaluated by SEM microscopy. Molecules, 19(11), 17773-17798. doi:10.3390/molecules 191117773 